\title{
Effects of Tinnitus Sound Therapy Depending on Stimulating Sound
}

\author{
Jeeun Yoo', Minseung Ku', Soon-Je Choi', In-Ki Jin² \\ 'Department of Speech Pathology and Audiology, Graduate School, Hallym University, Chuncheon, Korea \\ ${ }^{2}$ Division of Speech Pathology and Audiology, Research Institute of Audiology and Speech Pathology, College of Natural Sciences, Hallym University, \\ Chuncheon, Korea
}

\author{
Received: September 15, 2020 \\ Revised: September 21, 2020 \\ Accepted: September 21, 2020 \\ Correspondence: \\ In-Ki Jin, PhD \\ Division of Speech Pathology and \\ Audiology, Research Institute \\ of Audiology and Speech Pathology, \\ College of Natural Sciences, \\ Hallym University, \\ 1 Hallymdaehak-gil, \\ Chuncheon 24252, Korea \\ Tel: +82-33-248-2221 \\ Fax: +82-33-256-3420 \\ E-mail: inkijin@hallym.ac.kr
}

\begin{abstract}
Purpose: This study aimed to identify the effects of sound therapy according to various types of stimuli for 3 months in people with chronic tinnitus. Methods: Fifty-eight participants with chronic tinnitus based on inclusive and exclusive criteria were randomly assigned to one of the three groups: broadband noise group, nature sound group, and music sound group. Each group received sound therapy for 3 months and the level of stimulus was set to the level of the mixing point. To measure the change in participants' tinnitus, the Korean version of the Tinnitus Primary Function Questionnaire (K-TPFQ) was used at the initial and 3-month follow-up sessions. Results: In the mixed model analysis of variance, the main effects of time were significant in almost all the K-TPFQ categories, except for the hearing category. However, the main effect of groups was not significant in most of the K-TPFQ categories, except for the sleep category. The main effects of interaction with group $\times$ time were not significant. Conclusion: The results of this study indicate that sound therapy for 3 months could be effective in the management of tinnitus. However, no difference in the effect of sound therapy according to the type of stimuli was noted. These results show that sound therapy could be an effective method for people with tinnitus, regardless of the type of stimulus.
\end{abstract}

Key Words: Broadband noise, Music, Nature sound, Tinnitus

\section{INTRODUCTION}

이명은 외부 소리의 자극과 무관하게 머리나 귀에서 대상자 가 무의식적으로 소리를 인식하는 증상을 말한다(Jastreboff, 1990). 이명은 보통 간헐적으로 발생하며 몇 분 내에 사라지는 것이 일반적이다. 최근까지 이명이 아닌 일시적 귀 울림과 병적 이명을 구별하는 기준은 연구자 및 관점에 따라 다양할 수 있지 만, 몇몇 학자들은 공통적으로 5분 이상 지속되는 이명을 병리학 적인 이명으로 제안했다(Coles, 1984; Dauman \& Tyler, 1992). 이명의 유병률은 대상군과 지역에 따라 차이가 있지만, 일반적 으로 성인 인구의 약 $5 \sim 15 \%$ 에서 지속적인 이명이 발생한다고 보 고하였다(Heller, 2003). 만성 이명은 어느 연령대에서나 발생할 수 있지만 젊은 성인(5\%)보다 60세 이후 노인(12\%) 인구에서 더 많이 발생하는 것으로 알려져 있다(Eggermont \& Roberts, 2004). 이명은 두통, 집중력 저하, 우울증 등을 동반할 수 있으 며 이러한 이차적인 영향으로 인하여 삶의 질 저하를 초래할

(c) This is an Open Access article distributed under the terms of the Creative Commons Attribution Non-Commercial License (https://creativecommons.org/licenses/by-nc/4.0) which permits unrestricted non-commercial use, distribution, and reproduction in any medium, provided the original work is properly cited.
수 있다(Erlandsson \& Hallberg, 2000).

이명의 치료 및 재활은 원인에 따라 다양하게 적용할 수 있지 만 원인의 제거로 직접적인 치료가 가능한 일부 체성(somatosensory) 이명을 제외하고 대부분의 만성 이명은 이명의 관리 (management)를 통한 개선에 초점을 둔다(Kreuzer et al., 2013). 이명의 관리는 지각(perception)과 반응(reaction)의 개선으로 나눌 수 있다. 지각의 측면에서는 이명에 대한 인식을 감소(reduce awareness)시키는 것을 이명 관리의 목표로 한다. 지각은 소리치료(sound therapy)가 대표적으로 사용되는데 보청기 사 용, 음악청취, 차폐(masking), 소리강화(sound enrichment) 등 의 방법으로 이명의 관리가 주로 이루어진다(Henry et al., 2017). 반응의 측면에서는 부정적 반응을 감소(reduce negative response)시키는 것을 이명 관리의 주요한 목표로 한다(Henry et al., 2010). 반응은 교육과 상담으로 이명 관리가 이루어지는데 대표적으로 정보 상담(informational counselling), 자가 관리 교육(self-management skills education), 인지행동치료(cognitive behavioral therapy) 등의 방법을 사용하여 이명을 관 리한다.

소리를 활용한 이명소리치료 효과를 언급한 최초의 문헌은 
1821년 Jean Marie Gaspard Itard (1775 1838)의 'Traite des Maladies de l'oreille' 의학서에서 찾아볼 수 있는데, 흐르는 물 소리 또는 나무가 타는 소리가 이명으로 인한 고통을 줄이는데 도움을 줄 수 있다고 언급하였다(Stephens, 2000). 소리치료가 제안된 초기에는 차폐(masking) 방식을 주로 권고하였다. 차폐 는 이명에 대한 지각을 감소시키는 것을 목표로 한다(Vernon, 1976). 소리치료가 제안된 초기에는 이명에 대한 지각을 차단하 기 위한 완전 차폐(total masking) 방식을 주로 적용하였다 (Vernon, 1976). 하지만 1980년대 이후에는 이명에 대한 지각 의 감소에 초점을 둔 부분 차폐(partial masking) 방식이 제안 되었다(Hazell \& Wood, 1981). 차폐음의 종류는 주로 백색 잡 음, 협대역잡음, 그리고 광대역잡음을 주로 사용하였다. 그러나 선행 연구에 따르면 완전 차폐와 부분 차폐는 모두 이명 소리 의 일시적 완화에는 긍정적인 효과를 보였으나 지속적인 이명 소리의 제거 및 감소 또는 대상자의 이명에 대한 지각의 감소에 는 한계가 있다고 보고하였다(Hazell et al., 1985). 이후 Jastreboff \& Jastreboff(2000)는 기존 소리치료에서 발생하는 문 제점을 보완 및 수정하여 이명의 습관화(habituation)를 목표로 하는 소리치료를 제안하였다. 습관화는 이명 소리치료 시 사용 하는 자극음을 이명에 대한 일반적인 인식을 유지하는 강도인 동시에 충분히 낮은 수준으로 들리는 강도인 '혼합점(mixing point)' 강도로 소리치료를 진행하여 이명 소리에 대한 지각을 낮추는 것을 목적으로 한다. Jastreboff \& Jastreboff(2000)는 상담과 소리치료를 병행하는 신경생리학적 모델을 기반으로 이 명에 대한 부정적인 감정을 통제하고, 이명에 대한 반응과 의식 수준의 습관화를 통해 이명의 완화를 유도하는 이명재훈련치 료(tinnitus retraining therapy, TRT)를 제안하였다.

이명의 소리치료에 사용되는 자극음은 일반적으로 광대역잡 음, 음악 및 자연음 등을 음원으로 사용한다(Hoare et al., 2014). 특히, 광대역잡음은 소리치료에서 가장 오랜 기간 동안 사용되었 으며 보편적으로 사용하는 음원 중 하나이다(Jastreboff \& Hazell, 1993; Kim et al., 2014). 음향학적 관점에서 광대역잡음은 전 주파수에서 비교적 고른 에너지를 가지고 있어 증폭에 대한 특이성을 보이지 않는다. Kim et al.(2014)의 연구에서는 총 38 명의 주관적 이명 환자를 대상으로 광대역잡음, 이명 대상자의 피치와 일치하는 협대역잡음, 그리고 혼합음 (광대역잡음과 협 대역잡음을 혼합한 자극음)을 사용한 이명재훈련치료를 총 9주간 실시하였다. 연구 결과, 광대역잡음 그룹은 협대역잡음 및 혼합음 그룹에 비해 이명장애지수 설문지의 점수의 감소 정 도가 더 높은 것으로 나타났다. 이명장애지수 설문지는 점수가 감소할수록 이명으로 인한 악영향이 감소함을 의미한다. 이 연 구의 결과는 이명의 소리치료를 시행함과 자극음의 선정에 있 어서 소음을 활용한 이명 소리치료에서 광대역잡음이 효과적
인 자극음임을 시사한다.

음악을 매개로 하는 이명의 소리치료 역시 이명을 억제하는데 효과적인 자극음으로 사용이 가능하다(Al-Jassim, 1988; Davis et al., 2007). 음악은 광대역잡음이나 자연음과 같은 자극음과 달리 박자(tempo), 방식(mode), 키(key), 선율(melody) 및 리듬 (rhythm)의 변조가 다양한 특징을 가진다(Hann et al., 2008). 이명의 소리치료에 있어서 음악을 자극음으로 사용했을 때 발 생하는 장점으로는 이명 대상자에게 자극음을 제시하는 동안 편안함과 긍정적인 감정을 유발할 수 있으며(Yulis et al., 1975), 이명으로 인해 발생하는 두통과 같은 2차적 통증의 정도를 완 화시킬 수 있다(Whipple \& Glynn, 1992). Hann et al.(2008)의 연구에서는 총 13 명의 이명 환자를 대상으로 바로크 시대 음악 (4곡)과 소음 및 무음 조건(silence condition)에서 각각 5 분간 무작위 순서로 음원을 제시 후 이명성가심척도(Tinnitus Annoyance Scale, TAS) 및 자극성가심척도(Stimulus Annoyance Scale, SAS)를 측정하였다. 자극음에 따른 이명의 영향을 측정 하기 위해 사용된 TAS와 SAS의 척도는 모두 점수가 감소함에 따라 이명으로 인한 부정적 반응이 감소한 것을 의미한다. 연 구 결과, 4 개의 음악 자극 모두 소음 및 무음 조건보다 TAS 및 $\mathrm{SAS}$ 의 점수 감소가 두드러졌다. 특히 4가지 음악 자극음 중 2 가지(사계 中 봄, 바흐 $\mathrm{G}$ 오케스트라) 음악은 소음 및 무음 조 건보다 TAS 및 SAS에서 통계적으로 유의미한 감소를 보였다. 이 연구의 결과는 이명의 소리치료에서 음악을 음원으로 사용 할 때, 다른 자극음보다 더 긍정적인 영향을 미칠 수 있으며, 소 리치료에서 효과적인 음원이 될 수 있음을 시사한다.

이명 신경생리학적 모델에 따르면 이명으로 인해 생기는 부 정적 감정은 변연계와 자율신경계를 흥분시켜 부정적 재강화 현상을 일으킬 수 있기 때문에 부정적 반응을 유발하는 것은 이 명으로 인한 악영향을 강화하게 된다(Jastreboff \& Jastreboff, 2001). 즉, 부정적 감정을 일으키지 않는 소리를 자극음으로 선 정하여 이명의 소리치료를 수행하는 것이 중요함을 시사한다. Henry et al.(2006)의 연구에서는 총 21명의 이명 대상자에게 백색잡음, 100 1,400 Hz 중 특정 주파수 영역의 에너지만 포함 하는 다양한 협대역잡음, 자연음(nature sound), 물소리(water sound) 등 다양한 자극음의 노출 유무에 따라 발생하는 이명 의 짜증지수(annoyance)를 측정 및 비교 분석하였다. 연구 결 과, 250 4,000 Hz 사이의 에너지가 집중된 자연음과 물소리가 다른 자극음들에 비해 이명의 짜증지수에서 통계적으로 유의 미한 감소를 보였다. 이 연구의 결과는 이명의 소리치료에 있어 서 자연음을 사용하는 것이 이명에 대한 부정적인 반응을 일 으키지 않아 이명 소리치료에서 효과적인 음원일 수 있음을 시 사한다.

본 연구는 소리치료에서 주로 사용하는 음원 종류(광대역잡 
음, 음악, 자연음)에 따른 이명 소리치료 효과를 비교하고자 하 였다. 앞서 언급한 선행연구들(Hann et al., 2008; Henry et al., 2006; Kim et al., 2014)은 소리치료에 사용되는 다양한 음원 중 일부 음원 종류에 따른 효과를 비교하여 광대역잡음, 음악 및 자연음 각각의 유용성을 증명하였지만 재활 기간, 대상자 특징 및 결과를 측정하기 위한 설문지 종류 등이 연구마다 달 라서 이 중 어떤 음원이 더욱 효과적인지는 불명확하다. 광대역 잡음, 음악 및 자연음에 따른 소리치료 효과를 명확하게 보고 한 연구는 부재하지만, Henry et al.(2006)은 주파수 범위가 다 른 광대역잡음들과 다양한 자연음을 대상으로 소리치료 음원 을 청취하고 이명에 대한 짜증 정도를 측정한 결과, 자연음들을 청취할 때 광대역잡음들에 비하여 낮은 짜증 정도를 보였다고 보고하였다. 물론 이 선행연구는 소리청취에 따른 즉각적인 대 상자의 반응을 비교한 연구라 음원 종류에 따른 재활효과로 판 단하기에는 한계가 있지만 음원 종류에 따라 대상자의 짜증정 도의 변화가 나타날 수 있다면, 소리치료의 효과도 차이가 발생 할 수 있는 가능성을 어느 정도 시사한다고 볼 수 있다. 일반적 으로 이명치료 및 재활 효과는 짧게는 2 주에서 길게는 18 개월까 지 지속적인 시행 하에서 높은 효과들로 보고하였다(Henry et al., 2006; Tyler et al., 2018). 따라서 본 연구는 대표적으로 사 용하는 소리치료 음원 종류인 광대역잡음, 음악, 자연음으로 그 룹을 나누고 3개월간 지속적인 소리치료를 실시한 후에 소리치 료 효과를 비교함으로써 음원 종류에 따른 소리치료 효과의 차이를 비교하고자 하였다.

본 연구에서는 만성 이명 대상자에게 3 개월 동안 광대역잡 음, 음악 및 자연음을 사용하여 자극음 그룹별로 이명 소리치 료를 진행하고 자극음 종류에 따른 이명 대상자의 소리치료 효 과를 확인하고자 하였다. 또한 이명 소리치료를 통한 결과를 바탕으로 통계 분석을 통하여 음원(광대역잡음, 음악, 자연음) 에 따른 상호작용 여부를 확인하고자 하였다. 본 연구의 결과 는 이명 소리치료에서 효과적인 음원 선정에 관한 가이드라인 을 제공할 수 있을 것이다.

\section{MATERIALS AND METHODS}

\section{연구 대상}

본 연구는 58명(남 36명, 여 22명)을 대상으로 연구를 실시 하였다. 연구에 참여한 대상자의 평균 연령은 광대역잡음 그룹 (20명)의 경우 71.6[standard deviation (SD): 11.91]세였고, 음 악 그룹(20명)의 경우 43.6(SD: 8.98)세, 자연음 그룹(18명)의 경 우 43.8(SD: 6.40)세였다(Table 1). 그룹 간 연령 차이를 비교하 기 위해 일원배치 분산분석(one-way ANOVA)을 통해 분석 한 결과, 세 그룹 간 연령에 대한 차이가 유의미하게 나타났다 $[\mathrm{F}(2,57)=57.107, p=0.001]$. 이후 세 그룹 중 어느 그룹이 연 령 차이가 나타났는지 알아보기 위하여 사후검정(Bonferroni) 을 실시하였다. 그 결과 광대역잡음 그룹은 자연음 $(p=0.001)$ 및 음악 그룹 $(p=0.001)$ 과 유의미한 차이가 나타났으나, 음악 및 자연음 그룹 간 차이는 나타나지 않았다 $(p=1.000)$. 이명을 경험하고 있는 평균 기간은 광대역잡음 그룹의 경우 82.4(SD: 65.31)개월이었으며, 음악 그룹의 경우 90.6(SD: 77.53)개월, 자 연음 그룹의 경우 57.4(SD: 42.56)개월이었다. 세 그룹 간 이명을 경험하고 있는 기간에 따른 차이는 나타나지 않았다 $[\mathrm{F}(2,57)=$ $1.355, p=0.266]$. 초기 한국어버전 이명주요기능설문지(Korean version of the Tinnitus Primary Function Questionnaire, $\mathrm{K}-\mathrm{TPFQ}$, Shin et al., 2019) 전체점수는 광대역 그룹이 48.1(SD: 19.17)점, 음악 그룹이 46.3(SD: 20.55)점, 자연음 그룹 이 52.9(SD: 17.25)점이었고 그룹 간 통계적 차이는 나타나지 않았다 $[\mathrm{F}(2,55)=15.969, p=0.523]$.

\section{자극음}

본 연구는 광대역잡음, 음악 및 자연음을 사용하여 소리치료 를 진행하였다. 음악 및 자연음은 선행연구에서 효과를 보였다 고 보고한 음원 중에서 선정하였는데 음악은 비발디 '사계 (봄)' 로 선정하였고, 자연음은 '흐르는 물소리(running water sound)' 를 자극음으로 선정하였다(Hann et al., 2008; Henry et al., 2006). 소리치료를 위해 사용한 모든 음원은 Adobe Audition 3.0 (Adobe Systems Inc., San Jose, CA, USA)을 사용하여 음 원을 제작하였으며, 소리치료 음원은 $44,100 \mathrm{~Hz}$ 의 샘플링 속도

Table 1. Demographic characteristics of participants

\begin{tabular}{lccccc}
\hline \multirow{2}{*}{ Group } & $\begin{array}{c}\text { Age } \\
\text { (years) }\end{array}$ & $\begin{array}{c}\text { Duration of tinnitus } \\
\text { (months) }\end{array}$ & Male & Fex $(\mathrm{n})$ & \multirow{2}{*}{ Total score of K-TPFQ } \\
\cline { 4 - 5 } BBN & $71.6(11.91)$ & $82.4(65.31)$ & 12 & 8 & $48.1(19.17)$ \\
Music sound & $43.6(8.98)$ & $90.6(77.53)$ & 12 & 8 & $46.3(20.55)$ \\
Nature sound & $43.8(6.40)$ & $57.4(42.56)$ & 12 & 6 & $52.9(17.25)$ \\
\hline
\end{tabular}

Data are presented as mean (standard deviation) unless otherwise specified. BBN: broadband noise, K-TPFQ: Korean version of the Tinnitus Primary Function Questionnaire 
(sampling rate) 및 32 bits의 음원으로 제작하였다. 본 연구에 사용한 소리치료 음원의 주파수분석 결과를 Figure 1에 제시 하였다. 광대역잡음은 주파수별로 유사한 진폭을 보였으며, 자 연음은 저주파수 대역의 진폭이 고주파수에 비해 상대적으로 높은 진폭을 보였다. 음악은 자연음과 유사한 형태의 주파수 진폭특성을 보였으나 진폭의 변동(fluctuation)이 두드러지는 특징을 보였다.

\section{연구 절차}

본 연구는 인터넷을 통하여 연구참여 공고를 공지하였고 자 발적으로 연구 참여를 희망하는 82 명을 대상으로 전화 인터뷰 를 통하여 "이명을 겪으신 기간이 어떻게 되십니까", "현재 보청 기를 끼고 계십니까", “이명을 제외한 이과적 문제를 가지고 계 십니까"의 질문을 통하여 1차 대상자를 선별하였다(Table 2). 이명 기간의 경우 1년 이상의 만성 이명 대상자를 기준으로 선 정하였고, 보청기를 사용하고 있거나 이명과 관련된 치료 및 재 활을 받고 있는 대상자는 제외하였다. 1차 선별과정에서 18 명 이 그 기준에 부합하지 않아 제외되었다.

1 차 선별을 거쳐 선정된 대상자는 본교의 청각학 실습실에 방문하여 2차 선별검사를 진행하였다. 최종 연구참여자의 선정 기준은 Table 2에 제시하였다. 우선 청력검사기(GSI Tympster, Grason-Stadler, Eden Prairie, MN, USA)와 헤드폰(TDH-50, Teleponics Corporation, Farmingdale, NY, USA)을 통해 40 $\mathrm{dB}(\mathrm{A})$ 이하의 소음 조건에서 순음 청력검사(pure-tone audi- ometry)와 이명도 검사(tinnitogram)를 진행하였다. 순음 청력 검사 검사 결과 $500,1,000,2,000,4,000 \mathrm{~Hz}$ 의 청력 역치가 평 균 $40 \mathrm{~dB}$ 이하인 대상자를 연구대상자로 선정하였다. 이명도 검사는 이명 주파수 매칭 검사(pitch matching) 및 이명크기 측정 검사(loudness matching)로 구성하여 실시하였다. 주파 수 매칭검사 결과, 광대역잡음 그룹의 경우 $125 \mathrm{~Hz}$ 에서 2명, $250 \mathrm{~Hz}$ 에서 2명, $500 \mathrm{~Hz}$ 에서 2명, $750 \mathrm{~Hz}$ 에서 2명, $1,500 \mathrm{~Hz}$ 에서 3 명, $2,000 \mathrm{~Hz}$ 에서 2명, $3,000 \mathrm{~Hz}$ 에서 1명, 4,000 Hz에서 3 명, $8,000 \mathrm{~Hz}$ 에서 3 명으로 나타났으며, 음악 그룹의 경우 $1,000 \mathrm{~Hz}$ 에서 2명, $1,500 \mathrm{~Hz}$ 에서 1명, 2,000 Hz에서 2명, 3,000 $\mathrm{Hz}$ 에서 3명, 4,000 Hz에서 7명, $6,000 \mathrm{~Hz}$ 에서 1명, 8,000 Hz에 서 4명으로 나타났고, 자연음 그룹의 경우는 $500 \mathrm{~Hz}$ 에서 2명, $1,000 \mathrm{~Hz}$ 에서 3명, 2,000 Hz에서 1명, 4,000 Hz에서 3명, 6,000 $\mathrm{Hz}$ 에서 3명, $8,000 \mathrm{~Hz}$ 에서 6명으로 나타났다. 대상자의 이명 의 크기는 0에서 $20 \mathrm{~dB} \mathrm{SL}$ (sensation level) 사이에서 측정되 었다. 이명도 검사는 대상자의 이명 인식 여부를 확인하는 목 적으로 사용하였다. 또한 스마트폰을 통한 소리치료가 진행되 기 때문에 스마트폰을 가지고 있으며 사용에 어려움이 없는 대 상자로 한정하였고, 3 개월 동안 소리치료에 참여하길 희망하는 대상자를 본 연구의 적정 대상자로 선정하였다. 본 연구의 대상 자 제외조건은 다음과 같았다(Table 2). 이명의 어려움 및 이명 으로 인한 삶의 질 정도를 측정하는 설문지인 한국어버전 이명 주요기능설문지(K-TPFQ; Shin et al., 2019)를 작성하게 한 후 평균점수가 20점 이하인 대상자는 제외하였다. 이명주요기능
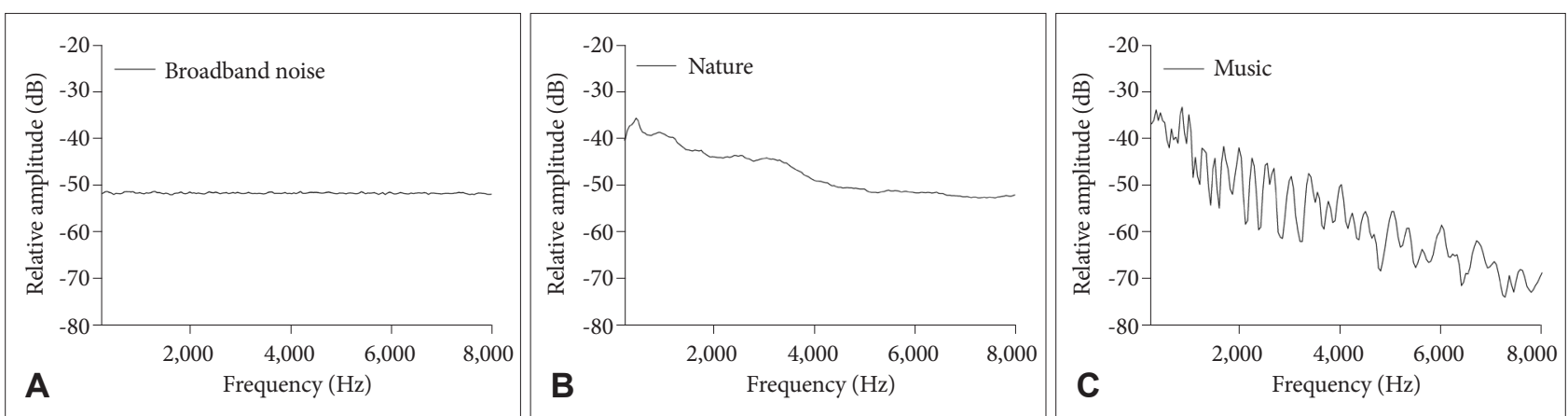

Figure 1. Results of frequency analysis of the broadband noise (A), nature sound (B), and music sound (C) groups as a function of frequency.

Table 2. Inclusion and exclusion criteria of participants for first and second screening

\begin{tabular}{|c|c|c|}
\hline Screening & Inclusion criteria & Exclusion criteria \\
\hline 1st screening & Persistent tinnitus for more than 1 year & $\begin{array}{l}\text { Otologic problems except tinnitus } \\
\text { (e.g., acoustic tumor, otitis media, and hyperacusis) } \\
\text { Using hearing aid or treatment other tinnitus therapy }\end{array}$ \\
\hline 2nd screening & $\begin{array}{l}\text { Pure tone average hearing thresholds of four frequencies } \\
(500,1,000,2,000 \text {, and } 4,000 \mathrm{~Hz}) \text { better than } 40 \mathrm{~dB} \text { hearing loss } \\
\text { Familiarity with smartphones usage } \\
\text { Willing to receive tinnitus sound therapy for } 3 \text { months }\end{array}$ & $\begin{array}{l}\text { Less than } 20 \text { scores (K-TPFQ) } \\
\text { History of psychiatric illness } \\
\text { History of litigation involvement }\end{array}$ \\
\hline
\end{tabular}

K-TPFQ: Korean version of the Tinnitus Primary Function Questionnaire 
설문지는 총 20 문항으로 구성되어 있으며, 4 개의 하위 항목(감 정, 청각, 수면, 집중)을 측정하는 문항이 각 5 문항씩 구성되어 있다. 각 문항은 0 100점 척도로 측정하며 점수가 높을수록 이 명으로 인한 악영향이 큰 것으로 해석한다. 종합 점수는 모든 문항 점수의 평균으로 계산하며, 13점 이상 감소한 경우에 유의 미한 감소로 판단한다(Tyler et al., 2020). 본 연구는 이명에 대 한 어려움을 가진 대상자를 연구참여자로 선정하기 위하여 소 리치료 전 이명주요기능설문지의 평균점수가 20점 이상인 대상 자를 연구의 대상으로 선정하였다. 또한 정신과적인 질환이 있 거나 이명 및 청각과 관련된 법적소송중인 대상자는 제외하였 다. 2차 선별과정에서 6 명이 연구조건에 부합하지 않아 제외되었 고, 최종적으로 58명이 본 연구의 최종 대상자로 선정되었다.

최종 선정된 대상자는 무작위 음원 선정에 앞서 음원에 대한 불쾌감 정도를 0 (불쾌감이 전혀 없음) 10 (매우 불쾌함)점 척도 로 측정하여 5점 이하로 측정된 음원 중에서 무작위로 할당하 였다. 음원에 대한 불쾌감 측정은 만약 대상자가 소리치료 음 원에 대해 불쾌감을 느끼는 경우, 소리치료의 효과보다 음원에 대한 불쾌감에 주의가 집중되어 연구 결과에 영향을 줄 수 있 다는 Henry et al.(2006)의 제언을 반영하여 진행하였다. 대상 자는 소리치료 전 연구동의서 및 개인정보 수집 동의서에 대하 여 설명을 듣고 서명하였다. 각 대상자는 초기검사 및 이명 소 리치료 3개월 후 검사를 위해 총 2회 방문하였으며 방문 검사 시마다 소정의 사례금을 지급하였다. 초기방문 시 대상자는 이 명 인터뷰(이명기간, 나이, 성별 등), 순음청력검사, 이명도 검사, 이명주요기능설문지 작성을 실시하였으며 3개월 소리치료 후 방문 시에는 순음청력검사 및 이명주요기능설문지 작성을 실 시하였다. 순음청력검사는 청력의 변화정도를 측정하기 위한 목적으로 진행하였으며 최초 검사 시와 $10 \mathrm{~dB}$ 이상 차이 나는 대상자는 없었다. 대상자는 하루 3 시간씩 소리치료를 시행하는 것으로 안내하였고 장시간 소음 청취에 대한 귀의 피로를 줄이 기 위하여 개방형(open type) 이어폰(ONE, MIJ, Chuncheon, Korea)을 제공하였다. 모든 대상자는 연구자가 대상자의 스마트 폰에 광대역잡음, 음악, 자연음의 소리치료 음원이 내장되어 있 는 어플리케이션을 설치하여 사용하도록 하였으며, 스마트폰 및 개방형 이어폰 사용법에 대해 충분한 정보를 제공받았다. 모든 대상자에게 원만한 소리치료를 위해 습관화 작용과 혼합 점 수준의 소리치료 음량에 대한 정보를 충분히 제공하였다. 소리치료는 대상자의 휴대전화를 사용하여 그룹별 이어폰을 착용하고 최저 강도에서 조금씩 강도를 높여 이명 소리가 최초 로 간섭 받는 수준인 혼합점(mixing point) 수준에서 실시하도 록 하였다. 대상자의 스마트폰에 설치된 어플리케이션은 볼륨 고정 기능이 있어 대상자가 임의로 볼륨을 변경하는 것을 방지 하였다. 또한 시간 고정 기능이 있어 하루 3 시간 청취 시 자동
으로 음원이 종료되어 개인마다 시간 차이가 나는 것을 방지하 였다. 본 연구의 목적은 음원 종류에 따른 소리치료 효과로 기 기사용 설명 및 일일소리치료 시간과 같은 연구진행에 관련된 설명을 제외하고 이명과 관련된 상담은 진행하지 않았다. 3 개 월간의 연구 종료 후 대상자에게 소리치료결과를 설명하였으며 이때 이명과 관련된 상담을 진행하였다.

\section{통계 분석}

본 연구는 3 개월간의 이명 소리치료 효과를 확인하기 위해 이명주요기능설문지 작성을 통해 소리치료 전후의 점수 차이 를 비교하여 이명 소리치료 효과를 확인하였다. 통계 소프트웨 어인 SPSS (Ver. 25, IBM Corp., Armonk, NY, USA)를 사용 하여 통계 검정을 진행하였으며, 혼합모델 반복측정 분산분석 (mixed model ANOVA with repeated measures)을 시행하여 소리치료 전후 측정 시기(초기, 3개월 후)에 대한 반복측정과 그룹(광대역잡음, 음악, 자연음) 간의 주효과 및 상호작용을 비 교하였다. 만약 그룹 간 혹은 그룹 내 결과의 통계적 유의미성 이 확인될 경우에는 그룹과 시간에 대한 영향을 독립적으로 확 인하고자 대응표본 $t$-검정을 사용하여 검증하였다. 본 연구에 서의 통계적 유의미성은 신뢰구간 $95 \%$ 의 기준으로 통계적 유 의미성을 확인하였다.

\section{RESULTS}

\section{기술 통계}

이명주요기능설문지의 전체 및 하위 범주(감정, 청각, 수면, 집중)에 대한 각각의 점수를 Table 3에 제시하였다. 이명주요기 능설문지의 전체(total) 점수를 비교한 결과, 광대역잡음 그룹 은 평균 48.1(SD: 19.17)점에서 31.8(SD: 21.30)점, 음악 그룹은 평균 46.3(SD: 20.55)점에서 39.5(SD: 19.15)점, 자연음 그룹은 평균 52.9(SD: 17.25)점에서 44.9(SD: 15.66)점으로 감소하였다. 감정(emotion) 항목에서 광대역잡음 그룹은 평균 56.5(SD: 17.52)점에서 40.0(SD: 26.10)점, 음악 그룹은 평균 59.7(SD: 25.88)점에서 51.4(SD: 24.45)점, 자연음 그룹은 평균 70.4(SD: 20.90)점에서 57.3(SD: 20.94)점으로 감소하였다. 청각(hearing) 항목에서 광대역잡음 그룹은 평균 45.0(SD: 23.25)점에서 23.0(SD: 18.91)점, 음악 그룹은 평균 38.6(SD: 25.77)점에서 32.9(SD: 24.23)점으로 감소하였고, 자연음 그룹은 평균 28.8(SD: 19.69)점에서 31.6(SD: 18.30)점으로 상승하였다. 수면 (sleep) 항목에서 광대역잡음 그룹은 평균 43.5(SD: 26.54)점에 서 34.0(SD: 24.91)점, 음악 그룹은 평균 36.5(SD: 26.36)점에서 31.6(SD: 20.71)점, 자연음 그룹의 경우 평균 60.5(SD: 16.52)점 에서 48.7(SD: 20.83)점으로 감소하였다 또한, 집중(concentra- 
Table 3. Average Korean version of the Tinnitus Primary Function Questionnaire scores of the BBN, nature sound, and music sound groups at pre- and post-treatment sessions

\begin{tabular}{|c|c|c|c|c|c|c|c|c|c|c|}
\hline \multirow{2}{*}{ Group } & \multicolumn{2}{|c|}{ Emotion } & \multicolumn{2}{|c|}{ Hearing } & \multicolumn{2}{|c|}{ Sleep } & \multicolumn{2}{|c|}{ Concentration } & \multicolumn{2}{|c|}{ Total } \\
\hline & Pre & Post & Pre & Post & Pre & Post & Pre & Post & Pre & Post \\
\hline $\mathrm{BBN}$ & $56.5(17.52)$ & $40.0(26.10)$ & $45.0(23.25)$ & $23.0(18.91)$ & $43.5(26.54)$ & $34.0(24.91)$ & $47.4(23.44)$ & $30.0(25.66)$ & $48.1(19.17)$ & $31.8(21.30)$ \\
\hline Music & $59.7(25.88)$ & $51.4(24.45)$ & $38.6(25.77)$ & $32.9(24.23)$ & $36.5(26.36)$ & $31.6(20.71)$ & $50.6(22.59)$ & $42.2(21.04)$ & $46.3(20.55)$ & 39.5 (19.15) \\
\hline Nature & $70.4(20.90)$ & $57.3(20.94)$ & $28.8(19.69)$ & $31.6(18.30)$ & $60.5(16.52)$ & $48.7(20.83)$ & $52.0(30.03)$ & $41.9(23.01)$ & $52.9(17.25)$ & $44.9(15.66)$ \\
\hline
\end{tabular}

Data are presented as mean (standard deviation) unless otherwise specified. BBN: broadband noise

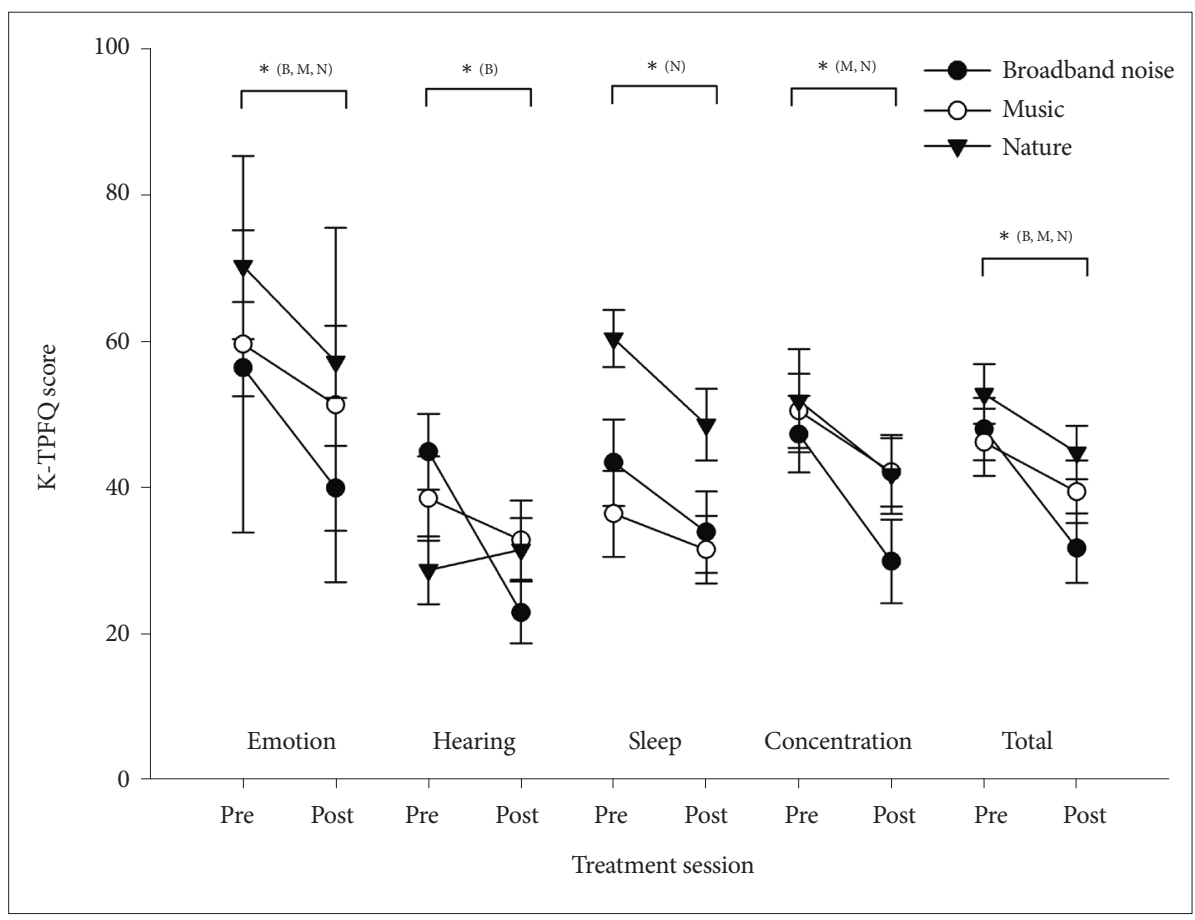

Figure 2. Korean version of the Tinnitus Primary Function Questionnaire (K-TP$F Q$ ) scores of emotion, hearing, sleep, concentration, and total categories for the broadband noise (B), music sound $(\mathrm{M})$, and nature sound (N) groups. *Statistical significance (paired $t$-test). tion) 항목에서 광대역잡음 그룹은 평균 47.4(SD: 23.44)점에서 30.0(SD: 25.66)점, 음악 그룹은 평균 50.6(SD: 22.59)점에서 42.2(SD: 21.04)점, 자연음 그룹은 평균 52.0(SD: 30.03)점에서 41.9(SD: 23.01)점으로 감소하였다.

\section{추리 통계}

혼합점 기반의 소리치료를 진행하고 소리치료 전후에 측정한 이명주요기능설문지에 대해 각각 2회 측정 시기(초기, 3 개월 후) $\times 3$ 그룹(광대역잡음, 음악, 자연음) 조건의 혼합모델 반복 측정 분산분석을 시행하였다. 또한, 그룹 내 소리치료 전후 차 이를 확인하기 위하여 대응표본 $t$-검정을 통해 이명주요기능설 문지에 대해 확인하였다. 이명주요기능설문지의 소리치료 전후 결과를 Figure 2에 제시하였고, 이명주요기능설문지에 대한 혼 합모델 반복측정 분산분석을 시행한 결과는 Table 4에 제시하 였다. 전체 점수 $[\mathrm{F}(1,55)=12.787, p<0.001]$ 를 포함하여 감정 $[\mathrm{F}(1,55)=18.237, p<0.001]$, 수면[F(1, 55) = 7.356, $p<0.001]$ 및 집중 $[\mathrm{F}(1,55)=12.983, p<0.001]$ 항목에서 측정 시기에 따
른 주효과가 유의미하게 나타났으나 청각 $[\mathrm{F}(1,55)=3.670, p=$ $0.061]$ 항목에서는 유의미하지 않은 결과로 나타났다. 그룹에 대한 주효과 결과에서는 전체 점수 $[\mathrm{F}(2,55)=1.321, p=0.275]$ 와 감정 $[\mathrm{F}(2,55)=2.626, p=0.081]$, 청각 $[\mathrm{F}(2,55)=0.703, p=$ $0.499]$ 및 집중 $[\mathrm{F}(2,55)=0.662, p=0.520]$ 항목에서는 유의미 하지 않았으나, 수면 $[\mathrm{F}(2,55)=6.408, p<0.001]$ 항목에서는 그 룹 간 유의미한 상호작용을 보였다. 즉, 그룹에 따른 소리치료의 효과는 수면 항목을 제외하고 유의미한 그룹 간 차이는 나타나 지 않았다. 그룹 간 비교를 위해 측정 시기 $\times$ 그룹의 상호작용을 확인한 결과, 이명주요기능설문지의 전체 점수에서 측정 시기 $\times$ 그룹의 상호작용은 유의미하지 않았다 $[\mathrm{F}(2,55)=0.648, p=$ 0.527 .

그룹과 시간에 대한 각 그룹 내의 독립적인 영향을 확인하기 위해 대응표본 $t$-검정을 실시한 결과 광대역잡음 그룹은 감정 $(t=2.384, p=0.002)$ 및 청각 $(t=2.138, p<0.001)$ 항목에서 유의미한 점수의 감소가 나타났으나, 수면 $(t=1.339, p=0.196)$ 및 집중 $(t=1.841, p=0.081)$ 항목에서는 유의미한 점수의 감 
Table 4. Results of the mixed model analysis of variance with repeated measures between time and group using the Korean version of the Tinnitus Primary Function Questionnaire

\begin{tabular}{lrrrc}
\hline \multicolumn{1}{c}{ Variables } & $\begin{array}{c}\text { Type III sum } \\
\text { of squares }\end{array}$ & df Mean square & $\mathrm{F}$ \\
\hline Emotion & & & & \\
$\quad$ Inter-group; group & 4281.629 & 2 & 2140.814 & 2.626 \\
Intra-group; time & 4277.801 & 1 & 4277.801 & $18.237^{* * *}$ \\
$\quad$ Time $\times$ group & 241.788 & 2 & 120.894 & 0.515 \\
Hearing & & & & \\
Inter-group; group & 985.106 & 2 & 492.553 & 0.703 \\
Intra-group; time & 973.406 & 1 & 973.406 & 3.670 \\
$\quad$ Time $\times$ group & 1413.178 & 2 & 706.589 & 2.664 \\
Sleep & & & & \\
Inter-group; group & 9293.274 & 2 & 4646.637 & $6.408^{* * *}$ \\
Intra-group; time & 2493.361 & 1 & 2495.361 & $7.356^{* * *}$ \\
$\quad$ Time $\times$ group & 290.442 & 2 & 145.221 & 0.428 \\
Concentration & & & & \\
Inter-group; group & 1233.948 & 2 & 616.974 & 0.662 \\
Intra-group; time & 3345.362 & 1 & 3345.362 & $12.983^{* * *}$ \\
$\quad$ Time $\times$ group & 154.279 & 2 & 77.140 & 0.299 \\
Total score & & & & \\
Inter-group; group & 1371.721 & 2 & 685.638 & 1.321 \\
Intra-group; time & 2619.425 & 1 & 2619.425 & $12.787^{* * *}$ \\
$\quad$ Time $\times$ group & 265.555 & 2 & 137.777 & 0.648 \\
\hline$* * * p<0.001$ & & & & \\
\hline & & &
\end{tabular}

소가 나타나지 않았다. 음악 그룹의 경우 감정 $(t=2.338, p<$ $0.001)$ 및 집중 $(t=2.618, p<0.001)$ 항목에서는 유의미한 점 수의 감소가 나타났으나, 청각 $(t=1.753, p=0.096)$ 및 수면 $(t=$ $1.224, p=0.236)$ 항목에서는 유의미하지 않은 점수의 감소가 나타났다. 자연음 그릅의 경우 감정 $(t=3.005, p<0.001)$, 수면 $(t=3.043, p<0.001)$ 및 집중 $(t=3.169, p<0.001)$ 항목에서 유의미한 점수의 감소가 나타났으나, 청각 $(t=0.552, p=0.588)$ 항목에서는 유의미하지 않은 점수의 감소가 나타났다. 또한, 전 체 점수로 비교한 결과, 광대역잡음 그룹 $(t=3.622 p<0.001)$, 음악 그룹 $(t=2.130, p<0.001)$ 및 자연음 그룹 $(t=2.463, p<$ 0.001) 모두에서 이명주요기능설문지 점수의 유의미한 감소가 나타났다.

\section{이명주요기능설문지 점수 변화에 따른 이명의 개선 효과}

이명주요기능설문지 결과를 통한 개인별 소리치료 효과를 확인하기 위해 소리치료 전후 평균 점수가 13점 이상 감소한 경 우를 기준으로 소리치료 효과를 확인하였다. 광대역잡음 그룹 은 20명 중 9명(45\%)의 대상자가 유의미한 점수의 감소를 보였 으며, 음악 그룹은 20명 중 3명(15\%)의 대상자가 유의미한 점수 의 감소를 보였다. 또한 자연음 그룹은 18 명 중 5 명 $(28 \%)$ 의 대 상자가 유의미하게 점수의 감소를 보였다. 또한, 하위 범주별로
확인한 결과 감정 항목의 경우 광대역잡음 그룹은 20 명 중 12 명(60\%), 음악 그룹은 20명 중 5명(25\%), 자연음 그룹은 18명 중 7명(39\%)이 유의미한 점수의 감소를 보였으며, 청각 항목의 경우 광대역잡음 그룹은 20명 중 8명(40\%), 음악 그룹은 20명 중 2명(10\%), 자연음 그룹은 18명 중 3명(17\%)이 유의미한 점수 의 감소를 보였다. 수면 항목의 경우 광대역잡음 그룹은 20명 중 10명 (50\%), 음악 그룹은 20명 중 7명(35\%), 자연음 그룹은 18 명 중 9명(50\%)이 유의미한 점수의 감소를 보였다. 또한, 집 중 항목의 경우 광대역잡음 그룹은 20명 중 9명 $(45 \%)$, 음악 그 룹은 20명 중 7명(35\%), 자연음 그룹은 18명 중 6명(33\%)이 유 의미한 점수의 감소를 보였다.

\section{DISCUSSIONS}

본 연구에서 시간(3개월)에 대한 주효과는 이명주요기능설 문지의 전체결과 및 청각 항목을 제외한 하위 범주에서 모두 유의미하게 나타났다. 그룹에 대한 주효과는 이명주요기능설문 지의 전체결과 및 수면 항목을 제외한 하위 범주에서 모두 유 의미하지 않은 결과를 보였다. 또한 시간과 그룹의 상호작용에 서는 모두 유의미하지 않은 결과를 보였다. 시간에 대한 주효과 를 보이지 않은 청각 항목의 경우 광대역잡음 그룹에서 초기 점수 평균이 45.0점에서 3개월의 소리치료 후 평균 23.0점으로 22.0점의 점수가 감소하여 유의미한 재활효과를 보였지만, 음 악 및 자연음 그룹에서는 각각 38.6점에서 32.9점으로 5.7점의 감소, 28.8점에서 31.6점으로 2.8점의 상승을 보여 이로 인한 영향으로 주효과의 차이가 나타나지 않은 것으로 추측할 수 있 다. 그룹에 대한 주효과를 보인 수면 항목의 경우, 자연음 그룹 에서 60.5점에서 48.7점으로 11.8 점이 감소하여 유의미한 감소 로 나타났으나, 광대역잡음 및 음악 그룹에서는 각각 9.5점 및 4.9점의 감소에 그쳐 유의미한 차이가 나타나지 않은 것으로 볼 수 있다. 본 연구의 결과, 세 그룹 모두 3 개월간의 이명 소리 치료에서 대체적으로 효과적인 이명설문지 점수의 감소가 나 타났으나, 시간과 그룹의 상호작용은 나타나지 않았기 때문에 음원의 종류에 따른 이명의 개선정도는 차이가 나타나지 않았 음을 시사한다.

본 연구에서 대응표본 $t$-검정을 실시한 결과, 소리치료 전후 에 유의미한 점수의 감소를 보이지 않은 그룹은 음악과 자연음 그룹의 청각 항목, 광대역잡음그룹과 음악 그룹의 수면 항목, 광대역잡음 그룹의 집중 항목으로 나타났다. Dauman \& Tyler (1992) 및 미국 이비인후과 임상실습 지침(Tunkel et al., 2014) 에 따르면, 이명 재활에 따른 효과는 개인에 따라 매우 다양할 수 있어 '평균데이터'만을 고려하는 것에 주의를 요한다고 보고 하였다. 따라서 소리치료 전후 점수 차이가 유의미하지 않게 나 
타난 항목의 경우, 개인별 소리치료 효과를 분석하였다. 소리치 료 전후에 유의미한 이명설문지 점수의 감소를 보이지 않았던 자연음 그룹의 청각 항목의 경우, 비록 18명 중 13점 이상 이명 설문지 점수의 감소를 보인 사람은 3 명이었지만, 이 3 명의 대상 자는 각 36점, 18 점, 26점의 큰 이명설문지 점수의 감소가 나타 났으며, 음악 그룹의 청각 항목의 경우에도 20 명 중 13 점 이상 이명설문지 점수의 감소를 나타낸 사람은 2 명이지만 각각 18 점 및 52점의 이명설문지 점수의 감소가 나타났다. 본 결과는 소리 치료를 통한 이명의 개선효과는 평균값 상에서의 비교에서는 유의미한 차이가 나타나지 않았더라도, 큰 폭의 이명설문지 점 수 감소가 나타난 대상자는 존재함을 확인하였다. 광대역잡음 그룹의 수면 항목의 경우, 20 명 중 13점 이상 이명설문지 점수 의 감소를 보인 대상자는 10 명으로 최소 14 점에서 최대 85 점의 이명설문지 점수의 감소를 보였으며, 음악 그룹의 수면 항목의 경우에도 18 명 중 13 점 이상 이명설문지 점수의 감소를 보인 대상자는 7명으로 최소 14점에서 최대 42점의 이명설문지 점수 의 감소가 나타나 소리치료를 통한 이명 개선의 효과가 나타난 대상자가 그룹내 존재함을 확인하였다. 광대역잡음의 집중 항 목의 경우에도 20 명 중 9 명이 유의미한 이명설문지 점수의 감 소가 나타났으며, 최소 14점에서 최대 80점의 이명설문지 점수 의 감소가 나타났다. 본 연구의 결과는 평균적으로 유의미한 이명설문지 점수 감소가 나타나지 않은 설문지 항목일지라도 개인에 따라 이명의 개선효과가 나타날 수 있음을 시사한다.

본 연구는 몇 가지 한계점이 있었다. 첫째, 본 연구는 그룹 간 연령의 차이가 있었다. 특히, 광대역잡음 그룹의 연령이 다른 그 룹에 비해 유의미하게 높았다. 이는 본 연구의 그룹 할당 방식 의 중점이 음원에 대한 불쾌감을 기준으로 진행된 과정에서 발 생한 한계점으로 볼 수 있다. 연령을 제외한 그룹별 평균 이명 의 기간과 초기 이명주요기능설문지 점수에서 차이가 없었기 에 그룹별로 유사한 이명의 기간과 이명으로 인한 어려움이 있 었다고 해석할 수 있으나 연령은 청각적인 능력 및 기능에 중요 한 영향을 미치는 요인이기에 향후 연구에서는 연령별 균형을 고려할 필요가 있을 것이다(Gates \& Mills, 2005). 둘째, 본 연 구는 주관적인 이명의 개선정도를 측정하는 설문지인 이명주 요기능설문지의 점수 변화를 통해 이명의 개선정도를 측정하 였다. 하지만 이명의 주파수 및 크기의 변화도 이명의 개선여부 를 측정하는데 도움이 될 수 있다. 본 연구에서는 초기검사 세 션에서만 이명도검사를 실시하여 3개월 재활에 따른 이명주파 수 및 이명의 크기 변화를 관찰할 수 없었다. 향후 연구에서는 설문지 점수의 변화와 더불어 이명도 검사결과의 변화를 함께 비교한다면 더욱 정확한 연구 결과를 제시할 수 있을 것이다.

본 연구는 다양한 자극음을 사용한 이명 소리치료의 효과를 확인하였다. 3 개월간 실시한 이명 소리치료는 이명주요기능설
문지 결과 전반적으로 소리치료 전후에 유의미한 이명설문지 점수의 감소를 보였다. 본 연구를 통해 광대역잡음, 음악 및 자 연음 음원이 소리치료에 효과적으로 사용될 수 있는 음원임을 확인하였다. 특히, 자극음 종류에 따라 소리치료의 효과 차이 가 나타나지 않았기 때문에 이명 대상자는 부정적 강화를 일 으키지 않는 자극음을 선택하여 소리치료를 시행한다면, 효과 적인 소리치료를 진행할 수 있을 것이다.

본 연구는 3 개월 동안 다양한 자극음 (광대역잡음, 음악, 자연 음)을 사용하여 소리치료를 진행한 후 자극음의 효과와 그 상 호작용을 비교하였다. 그 결과 소리치료 전후의 이명주요기능 설문지 점수는 모든 항목에서 유의미한 감소가 나타났으며, 다 양한 자극음을 사용한 소리치료가 이명으로 인해 겪는 청력과 수면 문제와 같은 불편함을 효과적으로 줄이는 것으로 나타났 다. 반면에, 자극음 유형에 따른 이명 소리치료의 효과 차이는 크지 않은 것으로 나타났다. 즉, 이명 소리치료에 영향을 미치 는 요인은 광대역잡음, 음악, 자연음과 같은 자극음의 유형이 아닌 시간, 개인의 내적 혹은 외적 요인으로 볼 수 있다. 또한 대상자 개개인마다 이명으로 인해 겪고 있는 고통은 다양하며, 고통의 정도 역시 다른 것으로 나타났다. 이는 효과적인 이명 소리치료를 위해 청각 전문가는 대상자가 이명으로 인해 어려 움을 호소하는 요인을 고려해야 하며 장기간의 이명 소리치료 를 위해 사용되는 자극음에 대한 대상자의 선호와 선택을 충 분히 반영하여 부정적 강화를 일으키지 않는 자극음을 선택하 는 과정이 필요할 것이다. 즉, 이명으로 인해 발생하는 문제에 초점을 맞추어 소리치료를 실행해야 할 것이다.

중심 단어 : 광대역잡음·음악·자연음·이명.

\section{Ethical Statement}

The study was approved by the Institutional Review Board of Hallym University (HIRB-2018-054-2-RC).

\section{Acknowledgments}

N/A

\section{Declaration of Conflicting Interests}

There are no conflict of interests.

\section{Funding}

This work has supported by the Commercializations Promotion Agency for R\&D Outcomes (Funding number: 2020 Customer Demand Correspondence Research-0002).

\section{Author Contributions}

I.J. designed experiments, analyzed data, and wrote the paper; J.Y. performed experiments, analyzed data, and wrote the paper.; M.K. \& S.C. performed experiments and analyzed data. Also, the authors discussed the results together and implications and commented on the manuscript at each stage. 


\section{ORCID iDs}

Jeeun Yoo

In-Ki Jin https://orcid.org/0000-0002-0217-8115

https://orcid.org/0000-0002-0834-5981

\section{REFERENCES}

Al-Jassim, A. H. (1988). The use of Walkman mini-stereo system as a tinnitus masker. The Journal of Laryngology and Otology, 102(1), 27-28.

Coles, R. R. (1984). Epidemiology of tinnitus: (1) prevalence. The Journal of Laryngology and Otology, 98(Supplement 9), 7-15.

Dauman, R. \& Tyler, R. S. (1992). Some considerations on the classification of tinnitus. In Aran, J. M. Tinnitus, 91: Proceedings of the Fourth International Tinnitus Seminar (pp.225-229). Amsterdam: Kugler Publications.

Davis, P. B., Paki, B., \& Hanley, P. J. (2007). Neuromonics tinnitus treatment: Third clinical trial. Ear and Hearing, 28(2), 242-259.

Eggermont, J. J. \& Roberts, L. E. (2004). The neuroscience of tinnitus. Trends in Neurosciences, 27(11), 676-682.

Erlandsson, S. I. \& Hallberg, L. R. (2000). Prediction of quality of life in patients with tinnitus. British Journal of Audiology, 34(1), 11-20.

Gates, G. A. \& Mills, J. H. (2005). Presbycusis. Lancet (London, England), 366(9491), 1111-1120.

Hann, D., Searchfield, G., Sanders, M., \& Wise, K. (2008). Strategies for the selection of music in the short-term management of mild tinnitus. Australian and New Zealand Journal of Audiology, 30(2), 129-140.

Hazell, J. W. \& Wood, S. (1981). Tinnitus masking-a significant contribution to tinnitus management. British Journal of Audiology, 15(4), 223230.

Hazell, J. W., Wood, S. M., Cooper, H. R., Stephens, S. D., Corcoran, A. L., Coles, R. R., et al. (1985). A clinical study of tinnitus maskers. British Journal of Audiology, 19(2), 65-146.

Heller A. J. (2003). Classification and epidemiology of tinnitus. Otolaryngologic Clinics of North America, 36(2), 239-248.

Henry, J. A., McMillan, G., Dann, S., Bennett, K., Griest, S., Theodoroff, S., et al. (2017). Tinnitus management: Randomized controlled trial comparing extended-wear hearing aids, conventional hearing aids, and combination instruments. Journal of the American Academy of Audiology, 28(6), 546-561.

Henry, J. A., Schechter, M. A., Zaugg, T. L., Griest, S., Jastreboff, P. J., Vernon, J. A., et al. (2006). Outcomes of clinical trial: Tinnitus masking versus tinnitus retraining therapy. Journal of the American Academy of Audiology, 17(2), 104-132.

Henry, J. A., Zaugg, T. L., Myers, P. J., \& Kendall, C. J. (2010). Progressive
Tinnitus Management: Clinical Handbook for Audiologists. (1st ed.), (pp. 59-97). Long Beach, CA: VA Employee Education System.

Hoare, D. J., Searchfield, G. D., El Refaie, A., \& Henry, J. A. (2014). Sound therapy for tinnitus management: Practicable options. Journal of the American Academy of Audiology, 25(1), 62-75.

Jastreboff P. J. (1990). Phantom auditory perception (tinnitus): Mechanisms of generation and perception. Neuroscience Research, 8(4), 221-254.

Jastreboff, P. J. \& Hazell, J. W. (1993). A neurophysiological approach to tinnitus: Clinical implications. British Journal of Audiology, 27(1), 7-17.

Jastreboff, P. J. \& Jastreboff, M. M. (2000). Tinnitus Retraining Therapy (TRT) as a method for treatment of tinnitus and hyperacusis patients. Journal of the American Academy of Audiology, 11(3), 162-177.

Jastreboff P. J. \& Jastreboff, M. M. (2001). Tinnitus retraining therapy. Seminars in Hearing, 22(1), 51-64.

Kim, B. J., Chung, S. W., Jung, J. Y., \& Suh, M. W. (2014). Effect of different sounds on the treatment outcome of tinnitus retraining therapy. Clinical and Experimental Otorhinolaryngology, 7(2), 87-93.

Kreuzer, P. M., Vielsmeier, V., \& Langguth, B. (2013). Chronic tinnitus: An interdisciplinary challenge. Deutsches Arzteblatt international, 110(16), 278-284.

Shin, J., Heo, S., Lee, H. K., Tyler, R., \& Jin, I. K. (2019). Reliability and validity of a Korean version of the Tinnitus Primary Function Questionnaire. American Journal of Audiology, 28(2), 362-368.

Stephens, D. (2000). A history of tinnitus. In Tyler, R. S. (1st ed.). Tinnitus Handbook (pp.437-448). San Diego, CA: Singular.

Tunkel, D. E., Bauer, C. A., Sun, G. H., Rosenfeld, R. M., Chandrasekhar, S. S., Cunningham, E. R., Jr, et al. (2014). Clinical practice guideline: Tinnitus. Otolaryngology--Head and Neck Surgery, 151(2 Suppl), S1-S40.

Tyler, R. S., Owen, R. L., Bridges, J., Gander, P. E., Perreau, A., \& Mancini, P. C. (2018). Tinnitus suppression in cochlear implant patients using a sound therapy app. American Journal of Audiology, 27(3), 316-323.

Tyler, R. S., Perreau, A., Powers, T., Watts, A., Owen, R., Ji, H., et al. (2020). Tinnitus sound therapy trial shows effectiveness for those with tinnitus. Journal of the American Academy of Audiology, 31(1), 6-16.

Vernon, J. (1976). The use of masking for relief of tinnitus. In Silverstein, H. \& Norrell, H. Neurological Surgery of the Ear: Volume II (pp.104-118). Birmingham: Aesculapius Publishing.

Whipple, B. \& Glynn, N. J. (1992). Quantification of the effects of listening to music as a noninvasive method of pain control. Scholarly Inquiry for Nursing Practice, 6(1), 43-58.

Yulis, S., Brahm, G., Charnes, G., Jacard, L. M., Picota, E., \& Rutman, F. (1975). The extinction of phobic behavior as a function of attention shifts. Behaviour Research and Therapy, 13(2-3), 173-176. 